\title{
Are sports image rights assets? A legal, economic and tax perspective
}

\author{
Dr Corinna Coors
}

\begin{abstract}
Although a general right of protection for a celebrity image or personality has not been recognised by the English Courts, it appears that commercially, the sports industry deals with image rights as an intangible asset. This was illustrated in the recent case of Proactive Sports Management Limited $v$ Rooney \& Ors where the Court of Appeal upheld a previous ruling by the High Court that an image rights agreement entered into by Wayne Rooney with an image rights company was unenforceable as it was in restraint of trade. ${ }^{1}$ The decision Sports Club Plc $v$ Inspector of Taxes also indicates that the process of assigning an image right to a company can be seen as a valuable asset at least for tax purposes, provided that arrangements are commercially genuine. ${ }^{2}$ Legal scholars in the UK have begun to explore how the field of law will and should respond to the growing commercialisation of image rights. Some suggest that the emerging significance of the commercial and tax value of image rights will have a transformative effect on the law. ${ }^{3}$ Others argue that existing legal concepts such as the law of passing off and trademark protection in the UK can accommodate whatever the value of image rights. ${ }^{4}$ This paper highlights the factors to consider in entering into sports agreements including the tax treatment applied to image rights and the recent update and commentary of the Inland Revenue (HRMC) to their capital gains tax manual on the taxation of image rights. ${ }^{5}$ The commentary of HRMC on image rights is yet another indication that, although traditional common law remedies will evolve further in the light of the growing commercialisation of image rights, a formal legislative or jurisprudential recognition of personality rights remains unlikely in the near future in the UK.
\end{abstract}

\section{Keywords}

Image rights, Intellectual Property, Sports agreements, Taxation,

\section{Introduction}

The value of name and images of celebrities has increased tremendously over the past decades. As sport has developed into a global business, sponsors are willing to pay large sums to align their companies, products and brands with them. ${ }^{6}$ As a result, famous athletes and their agents have realised the great earnings potential of using their image to sell

\footnotetext{
${ }_{1}$ Proactive Sports Management Ltd v Rooney \& Ors [2011] EWCA Civ 1444

2 Sports Club plc and others $v$ Inspector of Taxes [2000] STC (SCD) 44, Walsh, 260.

3 Walsh, 260.

4 Waelde and Laurie, 827; Blum and Ohta, 137.

5 See: http://www.hmrc.gov.uk/manuals/cgmanual/updates/cgupdate220714.htm [All websites accessed on December 15, 2014].

6 Blackshaw (2004) 13.
} 
marketing articles. ${ }^{7}$ For example, Cristiano Ronaldo, current FIFA World Footballer, earned more than half of his $\$ 52$ million income from commercial endorsements from sponsors in 2013. ${ }^{8}$ Despite retirement, the British football icon David Beckham earned \$42 million from commercial endorsements deals in $2014^{9}$ and has become an international brand in his own right. ${ }^{10}$

\section{What are image rights?}

In Proactive Sports Management Limited v Rooney \& Ors Lady Justice Arden defined image rights as a term "used to describe rights that individuals have in their personality, which enables them to control the exploitation of their name or picture." ${ }^{11}$ However, a typical image right clause in a sports licensing agreement will define image rights in rather broad terms and include, for instance filming, television and broadcasting rights as well as the right of a sportsman to control his identity, personality, name voice and likenesses in all forms of media. ${ }^{12}$ The facts of the case in Proactive $v$ Rooney were that in 2003, footballer Wayne Rooney, set up a company, Stoneygate Ltd, to exploit his image rights and he assigned his image rights to it. Stoneygate Ltd then appointed a sports agency, Proactive Ltd to act as its agent. The parties entered into an image rights agreement which allowed Proactive to negotiate endorsement contracts. The relationship lasted successfully for five years until the parties fell out and Stoneygate terminated the agreement and appointed another company in its place. Proactive took proceedings, claiming that Stoneygate was in breach of agreement, and that Proactive was entitled to commission due under the agreement. Stoneygate argued that Proactive was not entitled to commission and that the agreement was unenforceable on the grounds that it was unreasonable restraint of trade.

The Court of Appeal ruled that Proactive was not entitled to commission and upheld the High Court's decision that the agreement was unenforceable, as it was an unreasonable restraint of trade. The Court of Appeal argued that Mr Rooney had been primarily employed as a footballer, and his image rights were ancillary to this. As the contract was held to be unenforceable, Proactive was unable to enforce its contractual right to commission due under the agreement before or after the date that Stoneygate terminated the arrangement. The decision is significant as the Court of Appeal confirmed that a contract for the exploitation of image rights, or other ancillary activities to a person's main occupation, may constitute a restraint of trade. It follows that where businesses seek to negotiate image rights agreements they should ensure that such clauses only protect legitimate business interests and that they are no wider than what the courts consider reasonable. ${ }^{13}$

In Proactive v Rooney Arden LJ expressly highlighted the economic value of image rights: "(...), the endorsement of goods encourages the purchase and consumption of goods, and the court is entitled to assume that it is in the interests of the public that image rights should be fully realisable for this economic purpose.",14

\footnotetext{
7 Blackshaw (2005) 270.

8 http://www.forbes.com/profile/cristiano-ronaldo/.

9 http://www.forbes.com/profile/david-beckham/.

${ }_{10}$ Gardiner et al, pp 53-54.

11 Supra fn 1, para 1 per Lady Justice Arden.

12 Cloete et al, 176.

13 Woodhead and Baden-Powell, 114.

${ }_{14}$ Supra fn 1, para 93 per Lady Justice Arden.
} 


\section{International level of protection}

Despite the widely recognised commercial value of image rights, there is currently no international standard or harmonised legal concept for recognising an image right. ${ }^{15}$ While certain jurisdictions, such as the US, Germany and France offer statutory protection against the exploitation of an individual's image, English law provides no cause of action for the infringement of image rights as such. Although a celebrity may currently obtain protection through various statutory and common law rights, such as the developing law of privacy, breach of confidence and, in particular, the tort of passing off none of these rights were designed to protect image or personality rights. Many countries traditionally link the concept of personality rights to the right to privacy. ${ }^{16}$ While the former protects against economic loss caused by the commercial appropriation of an individual's personality the right to privacy protects against the intrusion of an individual's private sphere. ${ }^{17}$ It is worth noting that Guernsey, a small British island in the English Channel, has taken the creation and recognition of image rights to a new level by introducing a registrable statutory image right under its Image Rights (Bailiwick of Guernsey) Ordinance in 2012. ${ }^{18}$ Registration under the Ordinance creates a recognised defined image right for the first time which is published in Guernsey's Register of personalities and images. ${ }^{19}$ The proprietor of the registered personality obtains a legal property right similar to a trade mark which can then be assigned and licensed. ${ }^{20}$ Moreover, the proprietor of the registered image right has exclusive rights in the images registered against or associated with that registered personality. This new registration system for image rights has been welcomed by practitioners for bringing important clarity to the meaning and scope of image rights. ${ }^{21}$ However, it should be noted that a year after the establishment of the new system, it has not attracted as many registrations as expected. Potential registrants and celebrities may question the practical relevance of the remedy and its enforceability in other jurisdictions. Only the first high profile court case could put this new legislation to the test and effectively dispel concerns about the efficiency of the new system.

\section{The significance and value of image rights}

Image rights clauses in sporting contracts are often complex and have become one of the most disputed areas between clubs and their players. ${ }^{22}$ Wayne Rooney's recent $£ 70 \mathrm{~m}$ agreement with Manchester United was long being held up by negotiations over his image rights. ${ }^{23}$ Provided they are drafted properly, image rights agreements are an effective way of protecting image rights. ${ }^{24}$ A player can, for example, assign some or all of his image rights to a club as part of his contract, providing the employer with the rights to use his image to help sell tickets, shirts or other products and services. ${ }^{25}$ Image rights deals generally can account

\footnotetext{
15 Synodinou, 183.

16 Carty, 212.

17 Bainbridge, pp. 347, 882.

18 The Image Rights (Bailiwick of Guernsey) Ordinance, 2012.

19 Section 5 of the Image Rights Ordinance 2012.

20 Romer and Storey, pp. 51-56.

21 Parr, 20; Evans and Romer, 763.

22 Blackshaw (2012), 268.

23 http://www.theguardian.com/football/2014/feb/20/wayne-rooney-contract-talks-held-upmanchester-united

24 Gardiner et al, 443.

25 Cloete (2012), 556.
} 
for 10 to $20 \%$ of a player's contract. Below are important factors to consider when drafting an image right agreement.

\section{1) Sponsorship conflicts of interests}

Due to the growing conflicts between competing sponsors there are new challenges encountered by sportsmen and sponsors. ${ }^{26}$ Famous footballers may have entered image rights agreements with several different parties at once and it is therefore important to avoid any conflicts of interests. For example, a Premier League star may have an agreement with a third party exclusively for his benefit, such as sponsorship or boot deals; in addition he may have and arrangement with his club and team sponsors and thirdly he may have obligations under an image right agreement with the national team, where his image will be used to promote the goods of the national team sponsor. All of these different agreements must be carefully drafted and aligned by the legal representatives to ensure conflicts of interest do not adversely affect the athlete's ability to perform his functions properly under the contract. ${ }^{27}$

\section{2) Performance and Breach}

Image rights agreement should be carefully drafted to minimise the risk of ambiguity in such clauses. The parties' rights and obligations should be clearly defined to increase the likelihood that they will be effective in the event that a dispute arises. ${ }^{28}$ Sponsors or image rights companies would generally have the right to terminate a contract for failure to perform services properly. For example, an image right contract often requires the athlete to dedicate a minimum number of hours per week for marketing purposes and failure to turn up to such appointment can be a detriment to the company, especially if the sportsman is very famous and a new product is launched. The agreement should therefore clearly state the amount of merchandising work the player has to do for his club as part of his normal duties, such as for team photos and official club commitments. Other reasons for the termination of the agreement could be misconduct by athletes directed to other players or fans, any type of inappropriate conduct or alcohol on the premises during work hours. ${ }^{29}$

\section{3) Tax Avoidance}

Footballers, financial advisors and the clubs will often seek to use image right agreements as a probate remedy for tax avoidance. Such agreements can be used to reduce a player's income tax bill and his or her sports club's national insurance contributions. For example, in order to pay less national tax, the agents would separate image rights for foreign players from the rest of the standard terms in a player contract, such as basic wage, signing on-fees or loyalty fees. $^{30}$ The players' wage would still be taxed as ordinary personal income but image rights could be paid to an offshore company, for example in Jersey or Guernsey, two offshore territories in the English Channel, where tax could be paid at a much lower corporate rate.

In Sports Club, Evelyn and Jocelyn plc v Inspector of Taxes 2000, the Inland Revenue (HRMC) had challenged such image rights arrangements entered into by the premiership

\footnotetext{
${ }^{26}$ Hambrick and Moorman, 54.

${ }^{27}$ Blackshaw, 268.

${ }^{28}$ Welch in: Gardiner et al, 402.

${ }^{29}$ Boyd, 135 .

${ }^{30}$ Gordon, 207.
} 
football club Arsenal and two of its players, Dennis Bergkamp and David Platt. ${ }^{31}$ Bergkamp had his own image rights company incorporated in the Dutch Antilles in 1991 and had assigned his image rights to the company. Platt also had an offshore image right company which contracted with another company. Both players signed employment contracts with Arsenal Football Club in 1995. Arsenal signed separate agreements with their image rights companies which provided Arsenal with the right to exploit the player's image rights in return for an agreed fee. This fee was seen by HMRC as earnings arising from the player's employment and therefore taxable. HMRC viewed the image rights arrangements as a "smokescreen" which had been created in an attempt to disguise salary payments as image rights payments. Bergkamp, Platt and Arsenal appealed against this ruling to the Special Commissioners claiming that the image rights agreements were separate genuine commercial agreements that could be enforced.

The Special commissioners held that the arrangements were not "smokescreen" and that the payments made by Sports Club under the promotional agreement and the consultancy agreement were not emoluments to the players employment by Arsenal by virtue of section 19 of the Income and Corporation Taxes Act 1988 but genuine commercial agreements. ${ }^{32}$ The payments were seen as capital and commercial assets which had independent and separate value over the employment contracts.

\section{Recent developments}

Since the decision in Sports Club, there have been some changes in the taxation of image rights law. In 2006, HMRC launched an employment review to look into image rights payments, with cricket, rugby union and rugby league under scrutiny. ${ }^{33}$ A cap of $15 \%$ of remuneration payable for image rights exploitation was agreed in rugby union. In 2009 HMRC informed many Premier League Clubs that it was examining image rights payments to players from 2005 to 2008 . It has been reported that HMRC has since agreed with football clubs that image rights can only make up $20 \%$ at most of a player's total earnings. ${ }^{34}$ Since Agassi v Robinson (Inspector of Taxes (2006) residents outside the UK pay tax on their earnings in the UK and a share of sponsorship income, even if this income is earned through an offshore image rights company. ${ }^{35}$

In summary, although HMRC has taken action to prevent the abuse of sports image rights arrangements in the past, such structures are still effective if genuine and commercially appropriate. In assessing the genuineness and proportionality of image rights payments, the following points should be considered:

- The sum paid for the image rights should be a true and accurate reflection of the value of those rights.

- Negotiations should take place between the Image rights company and the club in relation to the value the club places on the image rights.

\footnotetext{
${ }^{31}$ Supra Fn 2.

${ }^{32}$ Supra Fn 2, para 91.

${ }^{33}$ Craggs and Mellors, 176.

${ }^{34}$ Ibid.

${ }^{35}$ Agassi v Robinson (Inspector of Taxes (2006) UKHL 23, 20061 WLR 1380.
} 
- The club's intention to exploit the image rights as well as the discussions and the valuation agreed upon should have been documented at board level.

- The promotional activity of the player should be monitored so that the club can decide whether it is receiving value for money and to inform future image rights negotiations. ${ }^{36}$

\section{HMRCs recent views on image rights}

This year, in an update to its practice manual HMRC has set out the position relating to image rights in the UK including their view on what constitutes an "image right" for tax purposes and whether it can be assigned or licenced to a third party. HMRC followed the general position of the English Courts and confirmed that under UK law there is no such thing as an "image right" as there is no legal process in the UK which protects the intellectual property rights (IPR) that identify an image or personality. ${ }^{37}$

\section{Are "image rights" goodwill?}

In the absence of an identifiable IPR e.g. registered trade mark or copyright, when an "image right" is assigned, the asset concerned must, in HMRC's view be goodwill. ${ }^{38}$ The law of passing off will protect the goodwill that a claimant has in his reputation. Following the case involving the racing driver Eddie Irvine (Irvine and others $v$ Talksport [2003]) where there is goodwill, misrepresentation and damage, the law of passing-off may be used in the UK to protect "image rights". 39

\section{Can "image rights" be assigned?}

Again, HMRC highlight that in the absence of identifiable IPR the assignment is likely to be of goodwill. ${ }^{40}$ HMRC refers to trade mark rights and acknowledges that, due to their registered nature, these may be considered to be readily assignable image rights and not goodwill. This is an important distinction and one which may prove useful to many clients in this position.

\section{Conclusion}

It has been demonstrated that sports image rights arrangements remain open to close scrutiny from HMRC, and therefore care should be taken to implement them correctly. Following the guidance provided in Sports Club, if image rights arrangements are to be effective, the taxpayer must establish that there is a commercial justification for the arrangements entered into. The recent guidance issued by HMRC gives practitioners and academics a valuable insight into HMRC's current thinking on the topic. HMRC largely followed the position of English Courts on what constitutes an image right and how it can be protected. This is yet another indication that, although traditional common law remedies will evolve further in the light of the growing commercialisation of image rights, a formal legislative or jurisprudential recognition of personality rights remains unlikely in the near future in the UK.

\footnotetext{
${ }^{36}$ Supra fn 34.

${ }^{37}$ See: http://www.hmrc.gov.uk/manuals/cgmanual/CG68405.htm.

${ }^{38} \mathrm{http}: / / \mathrm{www} . \mathrm{hmrc} \cdot$ gov.uk/manuals/cgmanual/CG68415.htm.

${ }^{39}$ Irvine \& Ors v Talksport Ltd. [2003] EWCA Civ 423.

${ }^{40} \mathrm{http}: / /$ www.hmrc.gov.uk/manuals/cgmanual/CG68420.htm.
} 


\section{REFERENCES}

1. David Bainbridge (2012) Intellectual Property Law, $9^{\text {th }}$ ed., Pearson, England.

2. Ian Blackshaw (2004) Protecting the images of sporting celebrities, Euro. Law., 36, pp. 12-13.

3. Ian Blackshaw (2005) Protecting sports image rights in Europe, Business Law International, pp. 270-273.

4. Ian Blackshaw (2012) Sports Marketing Agreements: Legal, Fiscal and Practical Aspects, TMC Asser Press, The Hague Netherlands.

5. Jeremy Blum and Tom Ohta (2014), Personality disorder: strategies for protecting celebrity names and images in the UK, Journal of intellectual Property Law and Practice, Vol 9, Issue 2, pp. 137-147.

6. Stephen Boyd (2011) Image rights contracts: morality clauses, Entertainment Law Review, 22(5), 133-135.

7. Hazel Carty (2004) Advertising, Publicity rights and English Law, Intellectual Property Quarterly, pp. 209-258.

8. Rian Cloete (2012) The taxation of image rights, a comparative analysis, De Jure 2012. 45 Vol. 3, pp. 556-567.

9. Rian Cloete et al (2005) Introduction to Sports Law in South Africa, $1^{\text {st }}$ ed, LexisNexis South Africa.

10. Adam Craggs and Nicole Mellors (2011) Getting physical - how the taxman is tackling image rights!, 22(6), Entertainment Law Review, pp. 175-176.

11. David Evans and Jason Romer (2013) A guide to Guernsey image rights, Journal of Intellectual Property Law and Practice, 8(10), pp. 761-763.

12. Simon Gardiner, John O’Leary, Roger Welch, Simon Boyes (2012) Sports Law, $4^{\text {th }}$ ed., Routledge, Oxon.

13. Keith M. Gordon (2012) Guide to the tax treatment of specialist occupations, Bloomsbury Professional, West Sussex.

14. Marion E. Hambrick; Anita M. Moorman, (2008) NASCAR Puts the Brakes on AT\&T: Sponsorship Conflicts of Interest and Contractual Rights, Sport Marketing Quarterly; Vol. 17 Issue 1, pp. 54-56.

15. Andrew Parr (2013), Good for your image, Intellectual Property Magazine, pp. 1920.

16. Jason Romer and Kate Storey (2013) Image is everything! Guernsey registered image rights, Entertainment Law Review, 24(2), pp. 51-56.

17. Tatiana Synodinou (2014) Image Right and Copyright Law in Europe: Divergences and Convergences Laws 3, pp. 181-207, doi:10.3390/laws3020181,ISSN 2075-471X.

18. Charlotte Waelde, Graeme Laurie (et al) (2013), Contemporary Intellectual Property, $3^{\text {rd }}$ ed., Oxford University Press.

19. Catherine Walsh (2013) Are personality rights finally on the UK agenda? European Intellectual Property Review, 35(5), pp. 253-260.

20. Jessie Woodhead and Ed Baden-Powell (2012), Proactive approach to restraint of trade (2012) Entertainment Law Review, 23(4), 113-114. 